\title{
Erratum to: Microarray (phylochip) analysis of freshwater pathogens at several sites along the Northern German coast transecting both estuarine and freshwaters
}

\author{
Julia Baudart ${ }^{1}$ - Delphine Guillebault ${ }^{2}$ Erik Mielke ${ }^{3}$ - Thomas Meyer ${ }^{3}$. \\ Neeraj Tandon ${ }^{4} \cdot$ Sabine Fischer $^{4} \cdot$ Wilfried Weigel ${ }^{4} \cdot$ Linda K. Medlin $^{5}$
}

Published online: 14 December 2016

(C) Springer-Verlag Berlin Heidelberg 2016

\section{Erratum to: Appl Microbiol Biotechnol}

DOI 10.1007/s00253-016-7937-2

The original article was updated because some proofcorrections were not implemented. The legends to figures 4 6 were updated as follows:

Fig. 4. Heat map of the relative abundance of (a) the bacterial hierarchical probes from family to kingdom and (b) from genus to species.
Fig. 5. Heat map of the relative abundance of (a) the protozoan hierarchical probes from family to kingdom and (b) from genus to species.

Fig. 6. a, b Hierarchical clustering of the sampling sites based on the similarity of their species profiles.

The reference below was missing:

Berndtsson, J.C, Paul, C.J. (2015) Microbiological pollution of the southern Baltic Sea from small urban catchments following rain events of different intensities. Vatten 71:27

The online version of the original article can be found at http://dx.doi. org/10.1007/s00253-016-7937-2.

Linda K. Medlin

lkm@mba.ac.uk

1 Sorbonne Universités, UPMC University Paris 06, CNRS,

Laboratoire de Biodiversité et Biotechnologies Microbiennes,

(LBBM), Observatoire Océanologique, F-66650 Banyuls/

Mer, France

2 Microbia Environnement, Avenue de Fontaule, 66550 Banyuls sur Mer, France

3 MariLim Aquatic Research, GmbH Heinrich-Wöhlk-Str. 14, 24232 Kiel, Germany

4 Scienion AG, Volmerstr. 7b, 12489 Berlin, Germany

5 Marine Biological Association of the UK, The Citadel, Plymouth PL1 2PB, UK 